\title{
Productive potential to contribute to food sovereignty througth technolgy packages generated by INIFAP
}

\section{Potencial productivo para contribuir a la soberanía alimentaria mediante paquetes tecnológicos generados por el INIFAP}

\author{
MOCTEZUMA-LÓPEZ, Georgel†*, ROMERO-SÁNCHEZ, Martín Enrique, GONZÁLEZ- \\ HERNANDEZ, Antonio and PÉREZ-MIRANDA, Ramiro
}

\author{
INIFAP. Cenid Comef \\ CVU CONACYT ID: 170859 \\ ID $2^{\text {nd }}$ Coauthor: Antonio, González-Hernández / ORC ID: 0000-0002-4329-4622 \\ ID $3^{\text {st }}$ Coauthor: Ramiro, Pérez-Miranda / ORC ID: 0000-0001-8449-8894
}

ID $1^{\text {st }}$ Author: Georgel, Moctezuma-López / ORC ID: 0000-0002-5605-7263, arXiv ID Author: 467145-7TPJMN-3BPJKF

ID $1^{\text {st }}$ Coauthor: Martín Enrique, Romero-Sánchez / ORC ID: 0000-0002-1682-6603, Scopus Author ID: 56705050200,

DOI: $10.35429 /$ EJRS.2019.9.5.13.22

Received August 15, 2019; Accepted December 28, 2019

\begin{abstract}
The research objective was to quantify INIFAP's contribution to food sovereignty by generating technological packages in the agriculture sector. The methodological process began with the integration of two research teams: one at the central level that was responsible for the coordination and elaboration of the productive potential mapping that was classified as high and medium of the most representative product systems in each state of the Mexican Republic and the other, he was responsible for updating the technological packages generated for the agricultural sector; subsequently, the review, homogenization, editing and publication of 32 Agricultural Technical Agendas was carried out. INIFAP contributed 483 technology packages nationally and the Northwest region was the one that contributed the most with 86 of them and at the entity level was the Estado de Mexico, which generated the most with 30 packages and the grasses were the most worked with 165 in which it was relevant corn that had a national cover and with 31 of them. Finally, the scientific community has a technological bibliographical collection that can be consulted for free on the INIFAP portal.
\end{abstract}

Innovation, Productive potential, Technological Packages

\begin{abstract}
Resumen
El objetivo de la investigación fue cuantificar la contribución del INIFAP a la soberanía alimentaria mediante la generación de paquetes tecnológicos en el sector agricultura. El proceso metodológico se inició con la integración de dos equipos de investigación: uno a nivel central que se encargó de la coordinación y de la elaboración del mapeo de potencial productivo que se clasificó como alto y medio de los sistemas producto más representativos en cada estado de la República Mexicana y el otro, se encargó de la actualización de los paquetes tecnológicos generados para el sector agrícola; posteriormente se realizó la revisión, homogenización, edición y publicación de 32 Agendas Técnicas Agrícolas. El INIFAP contribuyó con 483 paquetes tecnológicos a nivel nacional y la región Noroeste fue la que más aportó con 86 de ellos y a nivel de entidad fue el Estado de México, quien más generó con 30 paquetes y las gramíneas fueron las que más se trabajaron con 165 en las que es relevante el maíz que tuvo una cobertura nacional y con 31 de ellos. Finalmente, la comunidad científica cuenta con un acervo bibliográfico tecnológico que puede se puede consultar de manera gratuita en el portal del INIFAP.
\end{abstract}

Innovación, Potencial productivo, Paquetes tecnológicos

Citation: MOCTEZUMA-LÓPEZ, Georgel, ROMERO-SÁNCHEZ, Martín Enrique, GONZÁLEZ-HERNANDEZ, Antonio and PÉREZ-MIRANDA, Ramiro. Productive potential to contribute to food sovereignty througth technolgy packages generated by INIFAP. ECORFAN Journal-Republic of El Salvador. 2019. 5-9: 13-22.

\footnotetext{
* Correspondence to Author (email: moctezuma.georgel@inifap.gob.mx)

$\dagger$ Researcher contributing first author.
} 


\section{Introduction}

The National Institute of Forestry, Agricultural and Livestock Research is an entity that is dedicated to research for the rural sector and whose part of its functions is to generate in its experimental fields, knowledge known as technological packages which are disseminated through publications among which stand out those known as Agricultural Technical Agendas (ATA) and each of the federal entities of Mexico have one of them. Publications of research results, since the 1960s, of the then National Institutes of Agricultural, Livestock and Forestry Research (INIA, INIP and INIF), served as reference material for producers, students, teachers and researchers. These guides evolved, in the decade of the 90's, in which the INIFAP is formed, technologies are published at the institutional level by agricultural sector with application in the different agroecological areas of the country.

Currently, research activities, academic teaching and the work of society are permanently interrelated, as they provide knowledge and solutions to the present and future problems of society. In this context of constant exchange between research groups and academic bodies, of institutions dedicated to research and training of human resources associated with the rural sector; the project called "Update and improvement of agricultural technical agendas" was developed by INIFAP. This, broadly consisted of the compilation at national level of the agricultural technological packages generated in the research centers that make up the institute, with the purpose of capturing the knowledge and technological development available to the country's farmers, as well as the academic bodies that work in educational institutions in Mexico, to provide technological elements that affect the development of new research and support in the training of human resources dedicated to addressing the problems of the primary sector.

The ATA are prepared primarily as a source of dissemination of knowledge of the technologies that researchers generate at the national level and whose predominant vision is the welfare of the Mexican countryside.
The first beneficiaries in transferring this knowledge are agricultural producers, however, in the work of transmitting knowledge to producers, it is the extensionists who are trained by different academic bodies of education centers and research institutions. In this sense it is important to mention that the academic bodies are the set of departments, schools, faculties or academic units that belong to a Higher Education Institution (HEI) with thematic or disciplinary affinity, which are associated for the optimal use of human resources and materials (Moctezuma, 2017, Battista et al., 2015). Therefore, the importance of providing tools that are constantly updated and improved, since it is known that a good part of the production in the agricultural sector continues to present certain restrictions, which mainly include the lack of technological innovation, the result of the important lag in competitiveness consequence of the low levels of productivity in the productive structure that currently characterizes the sector, which is expressed in an agriculture with technological lag, as a result of the abandonment by the State policies towards smallholder farmers (Reyes, 2013, Chacue 2019). It is vital that the extension programs (agricultural, livestock, forestry and aquaculture) of Mexico continue with the budgetary support for their operation and even that the monetary resources are raised so that the technology transfer of the innovations that are generated arrive with greater promptness to the peasants. The objective of the research was to quantify the contribution of INIFAP to food sovereignty by generating technology packages in the agriculture sector so that they are freely available to farmers.

\section{Methodology}

A work team was integrated that fulfilled the necessary profiles to monitor and control the project activities, which included a team at the central level and another at the regional level. The first one was constituted in the National Center for Disciplinary Research in Conservation and Improvement of Forest Ecosystems where 5 researchers with multidisciplinary experience in areas such as dissemination, productive potential, agroecology, soils, planning, agrometerology, agronomy and socioeconomics were responsible for plan and coordinate the project and concentrate information nationwide. 
The second team was formed in the 43 Experimental Fields (CE) and eight Regional Research Centers (CIR): Northwest, North Center, North Center, Pacific Center, Center, Gofo Center, South Pacific and Southeast of INIFAP.

Subsequently, the following steps were followed for the development of the project:

1. The management was carried out before the General Directorate of the Institute for the designation of those responsible and support links for each Regional Research Center (CIR), where the collaboration of the 8 CIR (Northwest, North Center, Northeast, Pacific Center) was determined. Center, Gulf Center, South Pacific and Southeast). In addition, 74 researchers from the agricultural area were assigned to the project as responsible for the review, update and improvement of agricultural technology packages in each state of the republic.

2. A tuning workshop was held with the research team to discuss the scope, planning and logistics of the project, the impact and scope of the project. The activities and dates committed to the Produce Foundations Coordinator (COFUPRO) were presented. The fundamental idea was that the research team had the same level of knowledge and understanding of the research project.

3. The background of the 31 Agricultural Technical Agendas (ATA) that were prepared in the year 2015 (second edition) for the description of the characteristics of the states, the main technological packages of the regions, as well as the mapping was made descriptive of the soil (referenced by INEGI) so that the authors of the technological packages were based and familiarized with the structure of the agendas and so that the information was improved and updated.

4. An information validation meeting was held to receive feedback, review and make the necessary adjustments to the requirements requested from the $\mathrm{CIR}$, which consisted of a videoconference to inform the coordinating researchers of the eight Regional Centers and Experimental Fields, the tonic to follow through a critical route of activities for the coordination and implementation of the project.
- Information on the specifications of the requirements of the database of the technological packages was requested, requested by the Agrifood and Fisheries Information System (SIAP) of SAGARPA.

- The reception of the databases (technological packages), delivered by the Experimental Fields researchers, was coordinated by the central research team.

5. The project collaborators in the CIR made the drafting and correction of the technological packages that were selected and included in the ATA.

6. The technological information was concentrated in the CENID COMEF to monitor and verify the homogeneity of the data corresponding to the CIR, a comparative analysis was also made between what was generated in 2015 and 2017, both at the state and system level product and for this the following activities were carried out:

- Abbreviations of the ATA technology packages were approved.

- The corrections of the ordering of the technological packages were verified.

- The use of restricted pesticides in technology packages was justified.

- $\quad$ Prohibited pesticides were replaced by those established in the Official Pesticide Catalog of the Intersecretarial Commission for the Control and Use of Pesticides, Fertilizers and Toxic Substances (CICOPLAFEST).

- Technical adjustments of the technological packages were reviewed.

- Work was carried out on the development of maps of potential crop distribution by District of Rural Development (DDR) of the 31 States of the Mexican Republic.

- The representative photographs of each technological package were attached, as well as the photographs that illustrated the most relevant activities of the technological package. 
In the case of productive potential and in general, the following aspects were taken into account:

Agroecological requirements.- the crops that are listed in each of the ATA, thrive in a great diversity of environments, from the arid to the humid tropical ones and the requirements for each product system were the following: climate, temperature in its maximum meanings, average and minimum, rainfall, soil and topographic variables, altitude and slope.

The potential areas referred to the classification of land suitability, as a partial result of the evaluation and grouping of specific surfaces, in terms of their aptitude for specific use, which is based on the ecological requirements of the particular crop and conditions and characteristics of the sites, variables that condition the product systems and their levels of production and productivity.

For the delimitation of areas with productive potential in each state, the Hierarchized Analytical Process (AHP) that Saaty developed in 1997 was used, which solves complex problems with multiple criteria. Its functionality was structured in three levels: i) hierarchy, which represents the breakdown of the problem in its integral parts, ii) establishment of priorities between the elements of the hierarchy and iii) qualification of the relative preferences of the elements, based on a underlying scale, with scale of values from 1 to 9 .

\section{Results and Discussion}

In this sense, the project carried out by INIFAP updated and improved 31 agricultural technical agendas (one for each state of the country, with the exception of Mexico City), which are made up of different technological packages for crops established in the entities of the country, and that were generated by researchers working in the institute, in this work a technological package is conceptualized as the integration of a series of technological components aimed at improving the production and productivity of a specific productive system (for example technology for the cultivation of temporary beans in the Potosino highlands).
It should be noted that the National Service of Agrifood Health, Safety and Quality (SENASICA) in 2015 called for institutions (in addition to INIFAP) such as the International Maize and Wheat Improvement Center (CIMMYT); the Graduate College (COLPOS); the "Antonio Narro" Autonomous Agrarian University (UAAAN) and the Chapingo Autonomous University (UACh), to collaborate in the generation of 31 technical agendas; Due to the above, in the first part of the presentation of results, a comparison is made between the two years in which these agendas were published to determine the progress achieved with the INIFAP-led project.

The first comparison between the results obtained from the technical agendas generated in 2015 and 2017 is related to the amount of technological packages generated for the agricultural product systems grouped according to the regionalization of the eight INIFAP Regional Research Centers, Graphic 1 The regionalization presented in Graphic 1 is based on the categorization of the regions established by INIFAP according to the research centers that it has located throughout the national territory, the distribution of the states by regions is as follows:

- Northwest: Baja California, Baja California Sur, Sinaloa and Sonora.

- North Center: Aguascalientes, Chihuahua, Durango and Zacatecas.

- Northeast: Coahuila, Nuevo León, Tamaulipas and San Luis Potosí.

- Pacific Center: Colima, Jalisco, Michoacán and Nayarit.

- Central Gulf: Puebla, Tabasco and Veracruz.

- Center: State of Mexico, Guanajuato, Hidalgo, Querétaro and Tlaxcala.

- South Pacific: Chiapas, Guerrero, Morelos and Oaxaca.

- Southeast: Campeche, Quintana Roo and Yucatán. 
Technological packages included in the agricultural technical agendas by region, 2015-2017

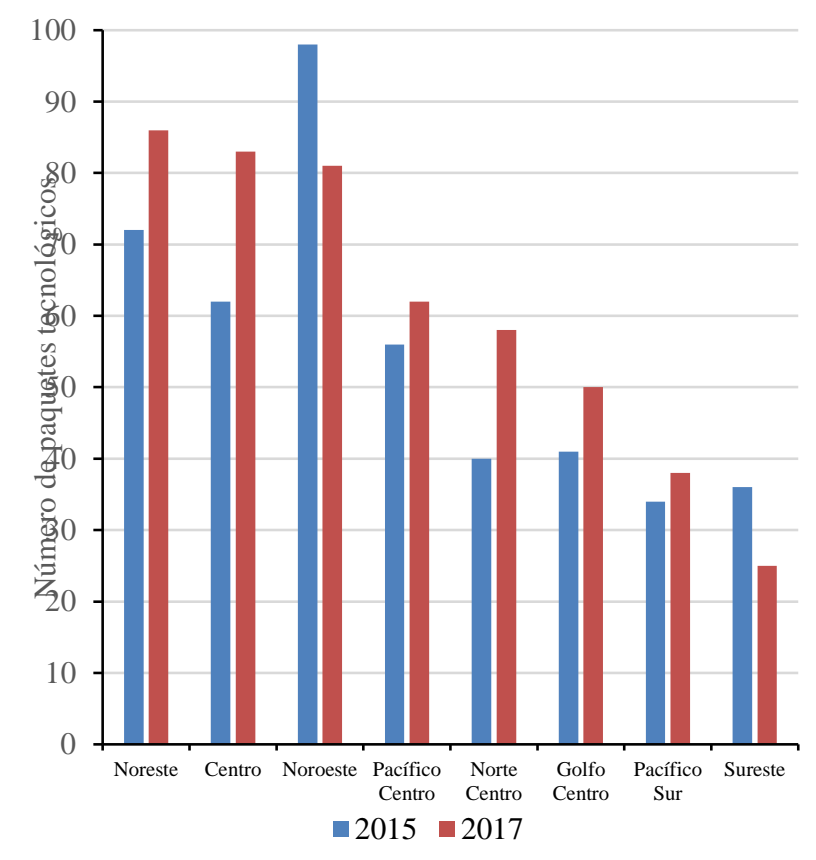

Graphic 1 Technological packages included in the agricultural technical agendas by INIFAP Regional Research Centers in 2015 and 2017

Source: own elaboration with INIFAP data

The region that contributed the largest number of technological packages was the Northeast, which includes the states of Tamaulipas, Nuevo León, Coahuila and San Luis Potosí, which represented $17.8 \%$ of the national total and between both entities they went from 72 packages to 86 , which it meant an increase of $19.4 \%$; followed in order of importance, the Central region, which concentrates five states (Guanajuato, Querétaro, Hidalgo, Tlaxcala and the State of Mexico), which went from 62 technology packages to 83, and with a participation of the technological offer of $17.2 \%$ and reached a growth of $33.9 \%$. The third place was occupied by the Northwest region that includes Baja California, Baja California Sur, Sonora and Sinaloa with 81 technology packages, however, it had a reduction in its growth of $-17.3 \%$ and its participation nationwide was $16.8 \%$. In the three regions mentioned above, $51.8 \%$ of the total offer of technology packages generated by INIFAP was reached. The region with the lowest participation was the Southeast, which includes Campeche, Yucatán and Quintana Roo, with only $5.2 \%$, which meant 25 technological packages and which, like the Northeast region, decreased by $-30.6 \%$.
At the level of the federal entity of the Mexican Republic, Graphic 2 shows the participation that each of the states had in the technological offer of the technological packages.

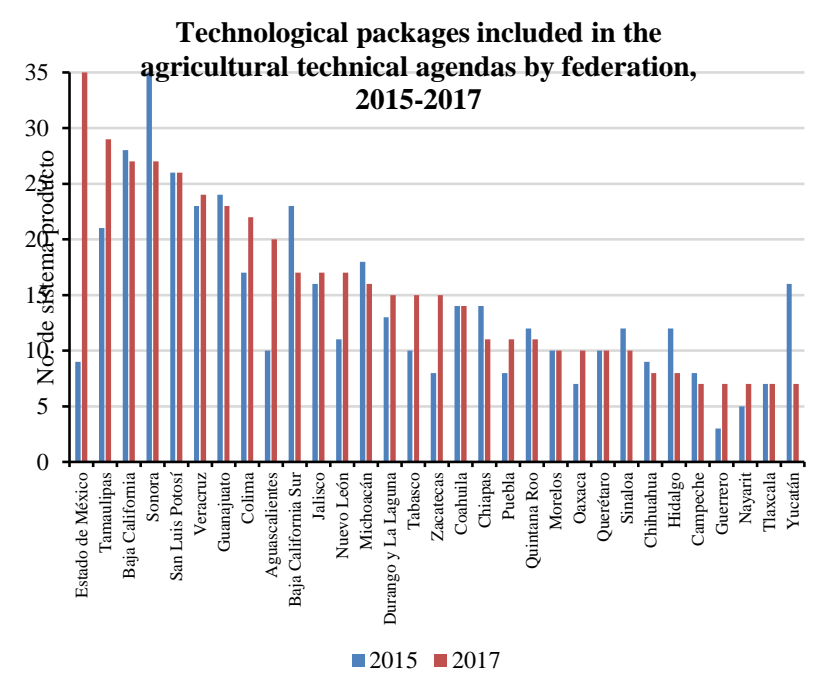

Graphic 2 Technological packages included in the agricultural technical agendas by federative entity of the Mexican Republic in 2015 and 2017

Source: own elaboration with INIFAP data

From the previous figure it follows that, in 2015, 107 product systems were published and in 2017 they were 113, which meant an increase in the period of 5.6\%. For the year of 2017, the State of Mexico was the one with the greatest contribution to the generation of technological packages since it reached the figure of 35 and represented $7.2 \%$ of the total, Tamaulipas followed in order of importance with 29 packages that meant $6.0 \%$ and thirdly, two states: Baja California and Sonora, both with 27 packages that represented $5.6 \%$ of each, among these four states, $24.4 \%$ (almost a quarter) of the technological offer is concentrated; On the other hand, the states with the lowest participation were five: Campeche, Guerrero, Nayarit, Tlaxcala and Yucatán, which contributed 35 packages (seven each state) and which accounted for $7.0 \%$. By way of illustration, a sample of 13 Agricultural Technical Agendas in various states of Mexico is shown in Annex 1.

A grouping was carried out by type of crop in seven classifications according to the INIFAP research programs, which were: grasses, fruit, vegetables, oilseeds, industrial, forages and ornamentals and are shown in Graphic 3. 
Technological packages included in the agricultural technical agendas grouped by crops, 2015-2017

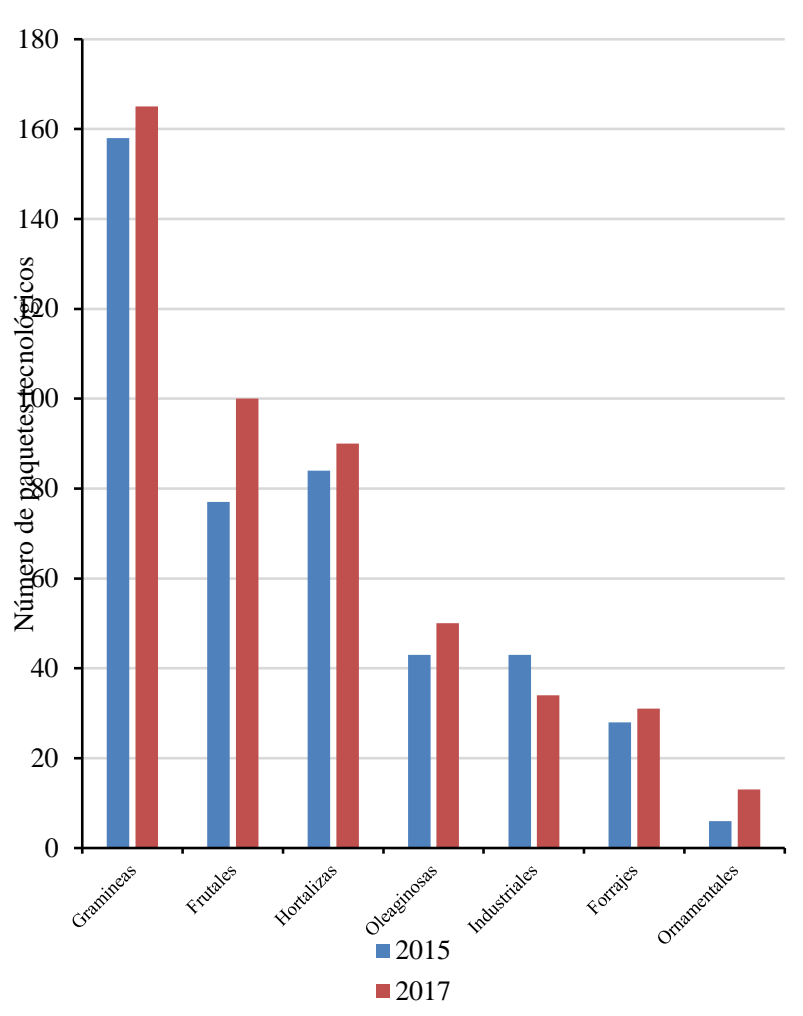

Graphic 3 Technology packages included in the agricultural technical agendas grouped by crops in 2015 and 2017.

Source: own elaboration with INIFAP data

With the exception of industrial crops, all other classifications increased their participation and the most representative is that of grasses, since in 2017 it represented $34.2 \%$ of the technological packages, which shows the vocation of INIFAP to attend the basic crops that are essential in the food diet of the Mexican people, immediately appear the fruit trees of temperate and tropical climate, deciduous and evergreen with $20.7 \%$ coverage, thirdly appeared vegetables that reached $18.6 \%$; Among these three types reached coverage of $73.5 \%$ (almost two thirds) of the technological offer and those that had a lower participation were ornamentals and forages, between both reached $9.1 \%$.

When analyzing the quantity of agricultural product systems that appear in the ATA's, 113 were reported and to make their graphic representation only $75 \%$ of them were taken, which are shown in Graphic 4,

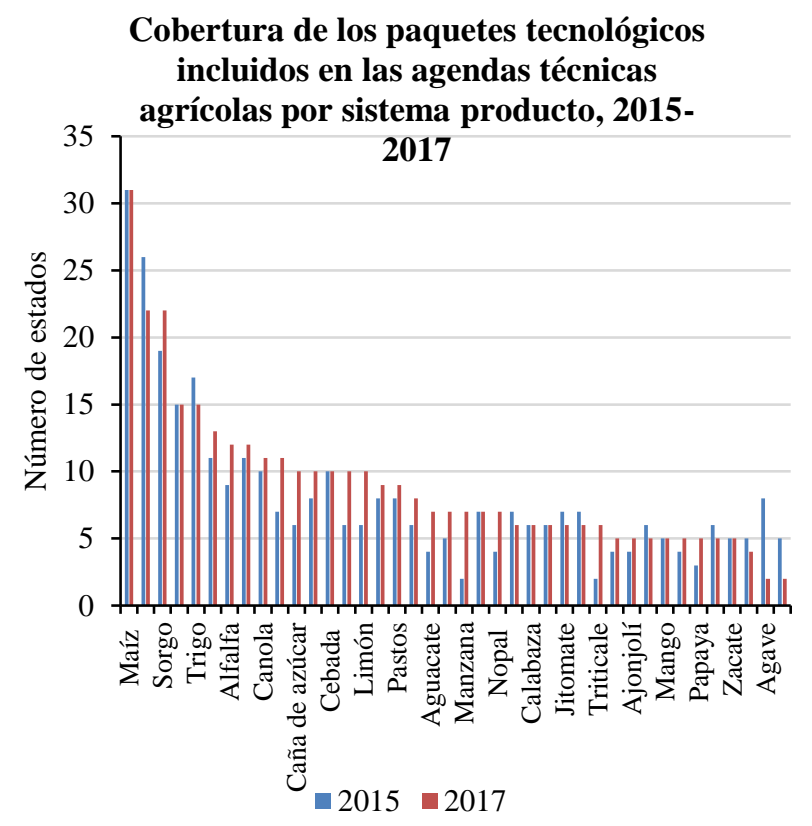

Graphic 4 Coverage of technological packages included in agricultural technical agendas by type of product system, 2015 - 2017

Source: own elaboration with INIFAP data

The fact that corn has a national coverage stands out from the above, in all states it is produced and in them INIFAP generated technological packages that adapt to the agroecological conditions of each entity. Corn represents its culture for Mexico and is a contribution to the world, since this grass is native to Mexico and is the staple food of the Aztecs since the founding of the Great Tenochtitlan and the coverage is in all the states of the republic; two other crops followed in order of importance: beans and sorghum in 22 entities, the first fundamental as a complement to human food and the second for livestock and essential in the preparation of balanced food, thirdly, also two grasses, oats and wheat, with coverage of 20 states and in fourth place was Chile with a coverage of 13 states and this confirms INIFAP's attention to what the Mexican people have: corn, beans and chili which are also fundamental in the production system known as milpa.

Among the product systems that had a low participation in terms of the number of states in which they were present are crops such as aloe and agave in two states, coffee in four and five, forage grass, tomato, papaya, walnut, peanut mango, sesame and garlic. 
The results obtained regarding the update and improvement of the ATAs in 2015 presented important similarities with those of the previous year, since the product systems such as corn, beans and sorghum remained the most important crops in terms of territorial quantity and coverage refers, in the case of corn, the number of states covered are the same (31), however, beans decreased their participation by $15 \%$, from 26 to 22 technological packages incorporated in the agricultural agendas of this year, on the contrary, sorghum increased its coverage by $16 \%$ when passing from 19 to 22 states, while technology linked to oat cultivation remained with the same proportion (15), while wheat decreased its participation in $12 \%$ ( 2 entities less compared to 2015), and Chile had an 18\% increase from 11 to 13 states; In this sense, similar behavior is shown in 2017 with respect to those published in 2015, in terms of the number of technological packages available per state for the different crops established throughout the national territory.

In the same order of ideas and to complement the analysis of the results obtained from the project related to the conformation of agricultural technical agendas, it is important to show interregional differences in the generation of technological innovations that in this case result in the amount of technological packages included in each agenda, this in order to observe the contrasts that exist between the different regions that make up the country.

The information that was spilled is consistent with the socioeconomic and productive polarization that characterizes the regions of the country, since on the one hand there are the northern and central states, which have a greater dynamism in terms of economic growth, in addition to own a mostly technical agriculture and dedicated to the production of crops of high commercial value (such as fruits and vegetables for export), while at the other end are the southern entities that have historically been marginalized and excluded from the processes of national development, which is expressed in an agriculture with technological lag resulting from the abandonment by the State policies towards smallholder farmers, in this sense the need to intensify research, innovation and technology transfer processes especially for small producers with scarce resources and low levels of well-being.
In this sense, the ATA's turn out to be fundamental tools to succeed in the production processes, improve the productivity of the economic units and increase the income of the farmers with a direct impact on their living conditions, because the packages Technological agendas are submitted, after being generated to a validation, transfer and adoption process by Mexican farmers.

This is due to the fact that the technological packages that make up the agendas contain the recommendations for the proper development of the different phenological stages of each crop, from the preparation of the land, seed varieties, sowing and fertilization, cultural work and irrigation, and therefore they are a substantial instrument, so that the technicians and institutions that are linked to the country's rural development processes, have at hand the most recent results of the research and technological innovations generated in this case by INFAP.

Regarding the productive potential, in each of the entities ATAS's, the maps of their distribution correspond to their areas with homogeneous socio-economic characteristics for agricultural activity under irrigation, temporary, drainage conditions defined by the SADER through the Rural Development Districts (DDR).

As an example, in the state of Chiapas, 80 maps are shown that considered 15 crops (garlic, coffee, cane, chili, beans, fig, tomato, Persian lemon, corn, mango, potato, pine nut, banana, sorghum and soy) in the 10 DDR of the entity and also the map of edaphology of the entity, its population in five levels, rainfall, average temperature and land and vegetation use.

Finally, as a result and output, the 31 Agricultural Technical Agendas are available on the platform of the INIFAP institutional page: http://www.inifap.gob.mx/SitePages/inifap2015 /Inicio/Agendas_Tec.aspx) to facilitate the Access to the general public, where they can view and download all files in reading format and which are also free. 


\section{Conclusions}

The work of the more than 70 INIFAP researchers that reflected in the 31 Agricultural Technical Agendas shows a great effort to compile improvement and update in technological packages of 113 product systems (20\% grasses, $29 \%$ fruit trees, $23 \%$ vegetables, $9 \%$ oilseeds , $11 \%$ ornamental and $9 \%$ industrial), throughout the country. This tool has three main users: producers, extension agents and the scientific community.

The ATAs are an instrument of economic development because the primary producer will find technologies that allow him to increase his average yields per hectare of the crops in which he works, which will allow him greater income or production technologies that reduce costs and by this means having a saving or not making a disbursement that make their production less profitable. The updating and improvement of the agendas was achieved, and they represent a variety of technological options as a support in the decision making of the producer, with the technical advice of their respective extension agents so that they can take options of other crops that they consider can take them to a better agronomic management of technological packages and to become experimental farmers that help the transfer of diverse technologies.

The scientific community obtains with the ATA's of the INIFAP a tool that has updated information of the technological packages that allows the diffusion of the knowledge generated and validated in the different regions of the country. It allows the technological understanding of the packages of your interest; The adoption of knowledge will have as a consequence a technological impact on the students and technicians that they train, which in turn tend to unleash a multiplier effect in their different work and development fields, which guarantees a contribution to the best development of the Mexican countryside.

\section{Annexes}

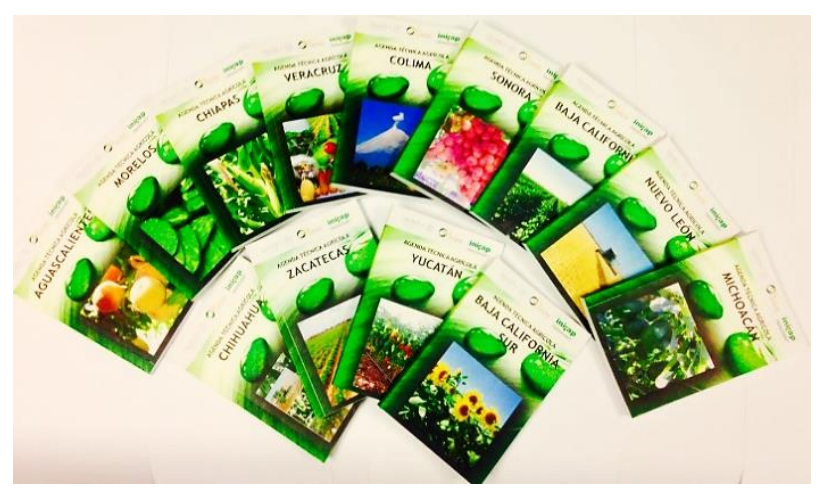

Figure 1

Photograph of some publications of Agricultural Technical Agendas.

\section{Acknowledgment}

To the Produce Foundations Coordinator for project financing.

\section{References}

Aguilar, S. S. (2005). Transferencia $e$ innovación tecnológica en la agricultura. Lecciones y propuestas. Michoacán: Universidad Autónoma de Chapingo/CIESTAAM.

Ávila, J. A. (2010). Del Extensionismo Agrícola a las Redes de Innovación. México: Centro de Investigaciones Económicas, Sociales y Tecnológicas de la Agroindustria y la Agricultura Mundial (CIESTAAM).

Battista, S. C., Feito, M. C., Cruz, A. O., Virdó, A. N., Irigoyen, M. S., Aznar, M. V., Almonacid, C. y Cohen Young, A. C. (2015). La potencialidad del sector agrícola matancero para un proceso de desarrollo sustentable: actualidad, antecedentes y perspectiva [archivo PDF]. San Justo: Universidad de La Matanza. Recuperado de:

http://repositoriocyt.unlam.edu.ar/handle/12345 $6789 / 217$

Chacue, V., \& Mauricio, J. (2019). La agroforestería como herramienta para el desarrollo agropecuario sostenible en el municipio de la Plata Huila. Universidad Nacional Abierta y a Distancia. Escuela de Ciencias Agrícolas, Pecuarias y del Medio Ambiente. Colombia: Recuperado de: https://repository.unad.edu.co./handle/10596/25 448

MOCTEZUMA-LÓPEZ, Georgel, ROMERO-SÁNCHEZ, Martín Enrique, GONZÁLEZ-HERNANDEZ, Antonio and PÉREZ-MIRANDA, Ramiro. GONZALEZ-HERNANDEZ, Antonio and PEREZ-MIRANDA, Ramiro.
Productive potential to contribute to food sovereignty througth technolgy packages generated by INIFAP. ECORFAN Journal-Republic of El Salvador. 2019 
Instituto Nacional de Investigaciones Forestales, Agrícolas y Pecuarias. 2017. Agenda Técnica Agrícola Aguascalientes. Ciudad de México, México.

Instituto Nacional de Investigaciones Forestales, Agrícolas y Pecuarias. 2017. Agenda Técnica Agrícola Baja California. Ciudad de México, México.

Instituto Nacional de Investigaciones Forestales, Agrícolas y Pecuarias. 2017. Agenda Técnica Agrícola Baja California Sur. Ciudad de México, México.

Instituto Nacional de Investigaciones Forestales, Agrícolas y Pecuarias. 2017. Agenda Técnica Agrícola Campeche. Ciudad de México, México.

Instituto Nacional de Investigaciones Forestales, Agrícolas y Pecuarias. 2017. Agenda Técnica Agrícola Chiapas. Ciudad de México, México.

Instituto Nacional de Investigaciones Forestales, Agrícolas y Pecuarias. 2017. Agenda Técnica Agrícola Chihuahua. Ciudad de México, México.

Instituto Nacional de Investigaciones Forestales, Agrícolas y Pecuarias. 2017. Agenda Técnica Agrícola Coahuila. Ciudad de México, México.

Instituto Nacional de Investigaciones Forestales, Agrícolas y Pecuarias. 2017. Agenda Técnica Agrícola Colima. Ciudad de México, México.

Instituto Nacional de Investigaciones Forestales, Agrícolas y Pecuarias. 2017. Agenda Técnica Agrícola Durango - La Laguna. Ciudad de México, México.

Instituto Nacional de Investigaciones Forestales, Agrícolas y Pecuarias. 2017. Agenda Técnica Agrícola Estado de México. Ciudad de México, México.

Instituto Nacional de Investigaciones Forestales, Agrícolas y Pecuarias. 2017. Agenda Técnica Agrícola Guanajuato. Ciudad de México, México.

Instituto Nacional de Investigaciones Forestales, Agrícolas y Pecuarias. 2017. Agenda Técnica Agrícola Guerrero. Ciudad de México, México.
Instituto Nacional de Investigaciones Forestales, Agrícolas y Pecuarias. 2017. Agenda Técnica Agrícola Hidalgo. Ciudad de México, México.

Instituto Nacional de Investigaciones Forestales, Agrícolas y Pecuarias. 2017. Agenda Técnica Agrícola Jalisco. Ciudad de México, México.

Instituto Nacional de Investigaciones Forestales, Agrícolas y Pecuarias. 2017. Agenda Técnica Agrícola Michoacán. Ciudad de México, México.

Instituto Nacional de Investigaciones Forestales, Agrícolas y Pecuarias. 2017. Agenda Técnica Agrícola Morelos. Ciudad de México, México.

Instituto Nacional de Investigaciones Forestales, Agrícolas y Pecuarias. 2017. Agenda Técnica Agrícola Nayarit. Ciudad de México, México.

Instituto Nacional de Investigaciones Forestales, Agrícolas y Pecuarias. 2017. Agenda Técnica Agrícola Nuevo León. Ciudad de México, México.

Instituto Nacional de Investigaciones Forestales, Agrícolas y Pecuarias. 2017. Agenda Técnica Agrícola Oaxaca. Ciudad de México, México.

Instituto Nacional de Investigaciones Forestales, Agrícolas y Pecuarias. 2017. Agenda Técnica Agrícola Puebla. Ciudad de México, México.

Instituto Nacional de Investigaciones Forestales, Agrícolas y Pecuarias. 2017. Agenda Técnica Agrícola Querétaro. Ciudad de México, México.

Instituto Nacional de Investigaciones Forestales, Agrícolas y Pecuarias. 2017. Agenda Técnica Agrícola Quintana Roo. Ciudad de México,

Instituto Nacional de Investigaciones Forestales, Agrícolas y Pecuarias. 2017. Agenda Técnica Agrícola San Luis Potosí. Ciudad de México, México.

Instituto Nacional de Investigaciones Forestales, Agrícolas y Pecuarias. 2017. Agenda Técnica Agrícola Sinaloa. Ciudad de México, México.

Instituto Nacional de Investigaciones Forestales, Agrícolas y Pecuarias. 2017. Agenda Técnica Agrícola Sonora. Ciudad de México, México. 
Instituto Nacional de Investigaciones Forestales, Agrícolas y Pecuarias. 2017. Agenda Técnica Agrícola Tabasco. Ciudad de México, México.

Instituto Nacional de Investigaciones Forestales, Agrícolas y Pecuarias. 2017. Agenda Técnica Agrícola Tamaulipas. Ciudad de México, México.

Instituto Nacional de Investigaciones Forestales, Agrícolas y Pecuarias. 2017. Agenda Técnica Agrícola Tlaxcala. Ciudad de México, México.

Instituto Nacional de Investigaciones Forestales, Agrícolas y Pecuarias. 2017. Agenda Técnica Agrícola Veracruz. Ciudad de México, México.

Instituto Nacional de Investigaciones Forestales, Agrícolas y Pecuarias. 2017. Agenda Técnica Agrícola Yucatán. Ciudad de México, México.

Instituto Nacional de Investigaciones Forestales, Agrícolas y Pecuarias. 2017. Agenda Técnica Agrícola Zacatecas. Ciudad de México, México.

Moctezuma L. G. (2017). "La ciencia en la universidad y la universidad con la ciencia: vinculación cuerpos académicos-equipos de investigación". Revista Mexicana de Agronegocios, 594-608.

Moctezuma L. G., E. U. Ramírez S., L. Velázquez F., R. Castillo F. y A. L. Castillo C. (2017) Actualización Mejoramiento de las Agendas Técnicas Agrícolas del INIFAP. Una Herramienta para 'Productores, Extensionistas y Cuerpos Académicos. Memoria XVII Encuentro Académico Nacional en Administración de Negocios y Disciplinas Afines. Ciudad de México. 2017. 198 pp.

Muñoz, M. (2007). INNOVACIÓN: motor de la competitividad agoalimentaria -Políticas y estrategias para que en México ocurra-. Estado de México: Universidad Autónoma de Chapingo-CIESTAAM/PIIAI.

Piñeiro. (1983). Cambio tècnico en el agro latinoamericano. Situaciòn y perspectiva en la dècada de 1980. San José Costa Rica: IICA.

Reyes, O. S. (2013). El Servicio de Extensión Rural en México. Propuesta de Política Pública. Biblioteca Pública de Agricultura. Guadalajara, Jal. México. 156 pp.
Romer, P. M. (1990). Endogenous Technological Change. Chicago: Journal of Political Economy 98.

Saaty, T. L. Toma de decisions para líderes. El Proceso Analítico Jerárquico: La Toma de Decisiones en un mundo complejo. RWS. Pittsburgh, PA, USA. 424 p

Solow, R. M. (1956). A Contribution to the Theory of Economic Growth. Oxfordshire, England: Quarterly Journal of Economics 70.

Swan, T. W. (1956). Economic Growt and Capital Accumulation. Oxfordshire, England: Economic Record.

Valencia Henao, D. V. \& Henao Bernal, I. D. (2019). De las prácticas agroalimentarias actuales a la soberanía alimentaria: alternativa accesible, saludable y ambientalmente responsable. Universidad de Manizales. Facultad de Ciencias Contables, Económicas y Administrativas 